\title{
The origin of volcanic rock fragments in Upper Pliocene Grad Member of the Mura Formation, North-Eastern Slovenia
}

\section{Izvor klastov vulkanskih kamnin v zgornjepliocenskem Graškem členu Murske formacije $v$ severovzhodni Sloveniji}

\author{
Polona KRALJ \\ Geološki zavod Slovenije, Dimičeva 14, SI-1109 Ljubljana
}

Key words: basaltic rocks, volcaniclastic sediments, Pannonian Basin, Mura Formation, Grad Member Upper Pliocene, Slovenia

Ključne besede: bazaltne kamnine, vulkanoklastični sedimenti, Panonski bazen, Murska formacija, Graški člen, zgornji pliocen, Slovenija

\begin{abstract}
Fresh-water, coarse-grained and detritus-dominated Mura Formation in NorthEastern Slovenia includes pyroclastic and volcaniclastic deposits originating from Upper Pliocene volcanic activity of basaltic geochemical character. Although localized in occurrence at the hamlet Grad, these pyroclastic and volcaniclastic sediments form a distinctive depositional unit, for which the term "Grad Member" is proposed and introduced in this paper.

In the Grad area no lavas or cinder cones are preserved, and the origin of volcaniclastic fragments still uncertain. For this reason, chemical composition of basaltic rock fragments from the Grad Member volcaniclastics has been studied and compared with basaltic rocks from the neighboring locations at Klöch, Kindsberg, Dölling and Neuhaus. The Grad Member pyroclastic and volcaniclastic deposits seem to be fed from the same source which is different from the occurrences in Austria. That supports the idea about the existence of a local volcanic centre in the present Grad area. The old volcanic edifices were possibly destroyed by the late-stage hydrovolcanic eruptions, and pyroclastic and volcaniclastic deposits subjected to constant reworking by fluvial currents in a dynamic sedimentary environment of alluvial fan and braided river systems.
\end{abstract}

\section{Kratka vsebina}

Sladkovodna Murska Formacija, katero grade predvsem debelozrnati sedimenti, vključuje piroklastite in vulkanoklastite, ki izvirajo iz zgornjepliocenskega vulkanskega delovanja bazaltnega značaja. Čeprav se pojavljajo ti sedimenti na zelo omejenem prostoru v okolici zaselka Grad, predstavljajo značilno sedimentacijsko enoto, za katero je v tem prispevku predlagano in prvič uporabljeno ime Graški člen Murske formacije.

V okolici Grada do sedaj še niso bile najdene lave ali stožci vulkanskega pepela in bomb skorje, zato ostaja izvor bazaltnih klastov v vulkanoklastitih Graškega člena še vedno nerazjasnjen. $\mathrm{V}$ ta namen smo preiskali in primerjali kemično sestavo odlomkov bazaltnih kamnin iz vulkanoklastitov Graškega člena in bazaltnih kamnin iz bližnjih lokacij na Klöchu, Kindsbergu, Döllingu in Neuhausu. Ugotovili smo, da so bazaltni klasti iz Graškega člena po sestavi med seboj podobni, vendar se od avsrijskih nahajališč značilno razlikujejo. To potrjuje domnevo, da je na področju Grada obstajal samostojen vulkanski center, čeprav danes ni več ohranjenih lavinih tokov ter stožcev vulkanskega pepela in bomb skorje. Starejše vulkanske oblike so najverjetneje porušile hidrovulkanske eksplozije v kasnem obdobju vulkanskega delovanja. Piroklastični in vulkanoklastični sedimenti pa so bili podvrženi nenehni presedimentaciji v dinamičnem okolju aluvialnega vršaja in prepletenih rek. 


\section{Introduction}

Fresh-water, coarse-grained and detritus-dominated Mura Formation in NorthEastern Slovenia includes pyroclastic and volcaniclastic deposits originating from Upper Pliocene volcanic activity of basaltic geochemical character. Although localized in occurrence at the hamlet Grad, these pyroclastic and volcaniclastic sediments form a distinctive depositional unit, for which the term "Grad Member" is proposed and introduced in this paper.

Upper Pliocene Grad Member consists of pyroclastic, syn-eruptive resedimented volcaniclastic and mixed volcaniclastic-fluvial deposits. Their formation is closely related to continental alkali basaltic volcanism which was active about 3 million years ago in the area of the present medieval castle and the surrounding hamlet Grad in Goričko, NorthEastern Slovenia. The volcanism forms a part of a broader volcanic province encompassing South Styrian Basin (Pöschl, 1991; Winkler, 1927; Poulditis, 1981; Poulditis \& Scharbert, 1986) and Little Hungarian Plain (Martin \& Németh, 2004), and developed as a consequence of postcollisional extension of the south-western realm of the Pannonian Basin.

At the present, no lavas are preserved in the Grad area, but only their fragmented remains (Plate 1 - Fig. 1) in volcaniclastic debris flow deposits. For this reason, doubts have been posed again recently about the existence of local volcanic centre in the

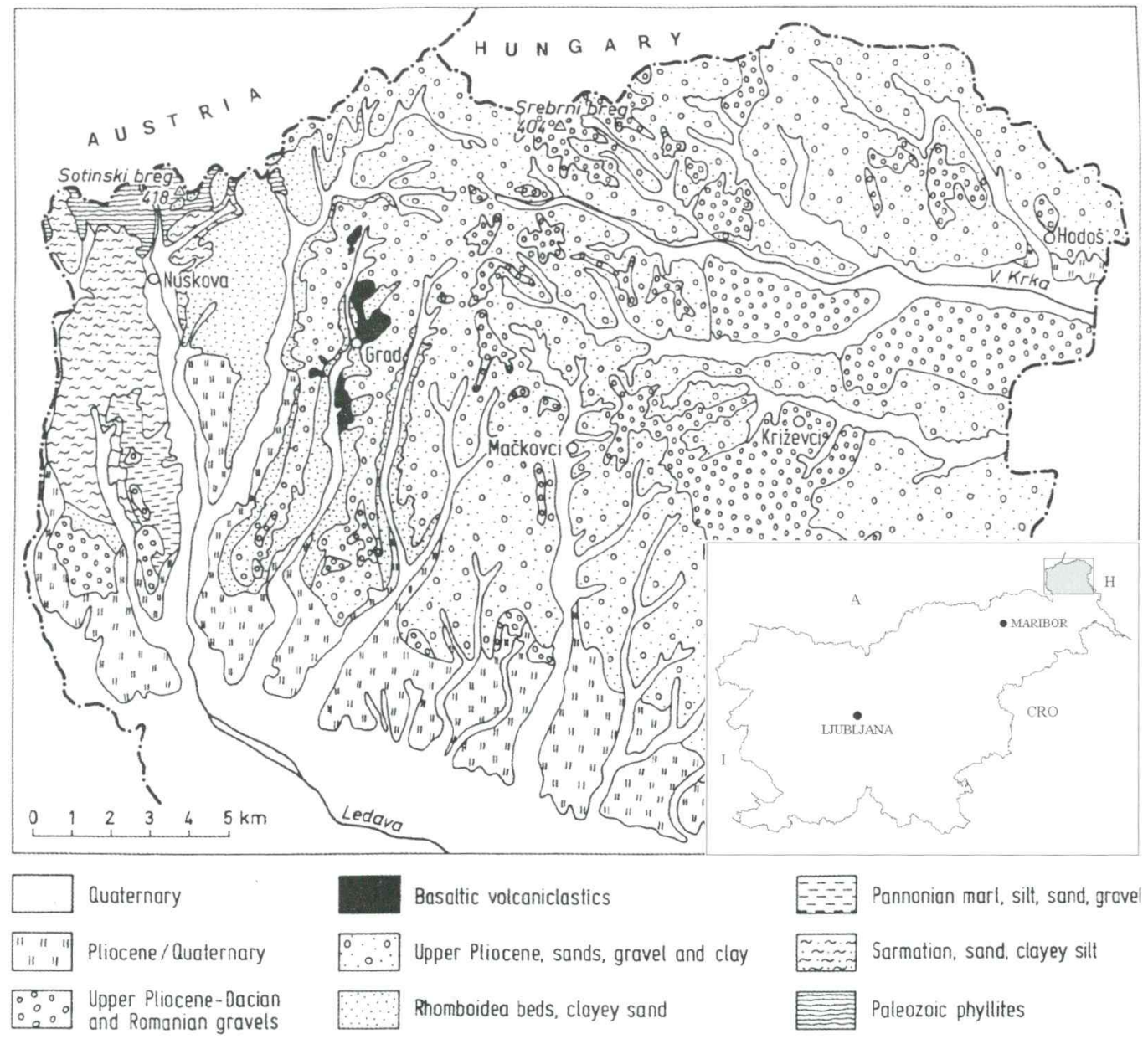

Figure 1. Simplified geological map of Goričko (after Pleničar, 1970)

Slika 1. Poenostavljena geološka karta Goričkega (po Pleničarju, 1970) 
Grad area (Martin \& Németh, 2004). Close proximity - about $10 \mathrm{~km}$ - of large lava flows on the crest of the South Burgenland Swell and in the neighboring Styrian Basin in Austria - at Stradner Kogel, Klöch, Kindsberg, Dölling and Neuhaus, supported a possibility that some of them might have been an additional source of volcaniclastic debris at Grad. The present contribution deals with detailed chemical composition of potential rock occurrences in Austria, and lava fragments in the Grad Member volcaniclastic rocks in order to characterize the source and consider possible paleotransport directions for volcaniclastic rock fragments of the Grad Member.

\section{Geological setting outline}

North-easternmost Slovenian territory (Fig. 1) is a hilly country that forms a part of the Mura Basin - the south-easternmost extending of the Pannonian Basin. The Mura Basin is filled with clastic, and to minor extent carbonate sediments, that range in age from Neogene to Quaternary. The Mura Basin consists of two depressions - northerly positioned southwest - northeast trending Radgona depression, and nearly west-east trending Ljutomer depression. They are separated by the Murska Sobota Swell (Kisovar, 1979). The Radgona depression is separated from the neighboring Styrian Basin in the north by the South Burgenland Swell (Tollmann, 1986; Oberhauser, 1980).

The basement of the Mura Basin mainly consists of Paleozoic metamorphic and clastic sedimentary formations; only in the deepest parts of depressions, Mesozoic carbonates are preserved. Tertiary sediments were deposited in a marine environment during Karpatian, Badenian and Sarmatian stage (Rijavec et al., 1985). Except for Badenian, they are developed as clastics - clays, marls, silts and sands.

During Pannonian, brackish conditions prevailed. Lower Pannonian sediments are silts and marls characterised by the occurrence of ostracods. They are overlain by the beds with Paradacna abichi molluscans, termed the »Abichi beds« (Pleničar, 1968). Overlying Lower Pliocene - Pontian sediemnts are mainly limnic, and consist of quartz sands, sandy silts and clayey silts. These deposits are regarded as »the freshwater equivalent of the Rhomboidea beds « (Pleničar, 1968). Middle Pliocene deposits overlie discordantly Pontian beds and are developed as sands and gravels. Fluvial sedimentation that started with Middle Pliocene persisted during Upper Pliocene and Quaternary.

Sarmatian sediments are united in the Murska Sobota Formation, Pannonian and Lower Pontian in the Lendava Formation, and Upper Pontian and Quaternary in the Mura Formation (Šimon, 1966).

During Pliocene, volcanic activity of basaltic composition occurred in the Styrian Basin and in the northern margins of the Radgona depression. On the crest of the South Burgenland Swell large lava flows occur (Fig. 2). Towards the north, maars, tuff rings and tuff cones are more common in occurrence. Strongly differentiated and alkalies-rich varieties include nephelinites, basanites, nepheline basanites, thrachybasalts and alkali basalts. Peridotite and/or lherzolite xenoliths are common and indicate the origin of magmas and their rapid ascend towards the surface (Embey-Isztin \& Kurat, 1996).

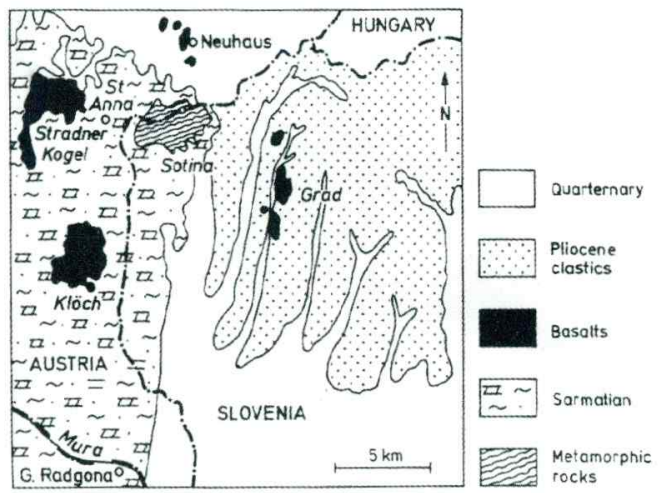

Figure 2. Simplified geological map of the Grad area with the neighbouring outcroppings of basaltic rocks in Austria (after Pleničar, 1968 \& Winkler, 1927)

Slika 2. Poenostavljena geološka karta območja Grada z bližnjimi izdanki bazaltnih kamnin v Avstriji (po Pleničarju, 1968 in Winklerju, 1927)

Volcanic activity at Grad occurred in an active continental sedimentary environment characterized by alluvial fan and braided river systems (Kralj, 2000 b). Rapid deposition of coarse-grain dominated detritus was closely related to the rise of the South Burgenland Swell and the subsidence of the Radgona depression. During Early Pliocene, a system of alluvial fans formed along the 
south-eastern slopes of the South Burgenland Swell, and towards the south, east and south-east it continued as a system of braided rivers, although the main transport direction was from north-west to south-east. The present maximum thickness of clastic deposits in the Radgona depression amounts to about $2000 \mathrm{~m}$. Lavas and pyroclastic deposits occurring in such active depositional environment had little preservation potential and rapidly underwent redistribution by fluvial currents. Magmas ascending towards the surface reached water-bearing strata and consequently, and with the time, the style of eruptions became essentially influenced by hydrovolcanic processes. Their violent explosions additionally contributed to destruction of primary volcanic edifices and lavas (Plate 1 - Figure 1) which already had little preservation potential in such dynamic fluvial sedimentary environment (Kralj, 1995; 2000a, b).

\section{Chemical composition of alkali basaltic rocks}

Chemical composition of alkali basaltic rocks in Styria and Burgenland is extensively treated by Poulditis (1981) and Poulditis \& Scharbert (1986). Their absolute age was determined by Balogh et al. (1994). At Stradner Kogel, the most differentiated varieties - nephelinites occur in the form of lava massive. At Klöch and Kindsberg, lavas of nephelinite basanite composition outcrop. At Neuhaus, alkali basalts occur. They penetrated soft sands, probably soaked with water, and consequently, they underwent extensive autobrecciation (Plate 1 - Fig. 2). In such form, they could be easily eroded and transported by water currents.

In order to minimize analytical errors related to procedures in different laboratories, rock samples from potential locations in Austria were analyzed in the same laboratory and under the same analytical conditions as the samples from Grad. The analyses were performed in X-RAL Activation Services Inc. in Ann Arbor, Michigan and Don Mills, Ontario, and it encompasses determination of 73 elements by combined wet chemical method, atomic absorption spectroscopy, and inductively coupled plasma source and mass spectroscopy.

The rocks from Klöch, Kindsberg, Dölling and Neuhaus were determined as potential sources with respect to the general pa- leotransport direction. Stradner Kogel was eliminated in the first place since the composition of nephelinite lavas is too declined from the composition of lava clasts from of the Grad Member volcaniclastics as evidenced from preliminary petrographic studies. Chemical composition of the studied rocks is shown in Table 1 and Table 2 .

General overview of chemical analyses indicates that among major oxides silica and $\mathrm{K}_{2} \mathrm{O}$ do not differ significantly in the studied samples. The rocks from Austria have higher abundance of $\mathrm{TiO}_{2}, \mathrm{CaO}, \mathrm{MgO}$ and $\mathrm{Na}_{2} \mathrm{O}$, and are lower in $\mathrm{P}_{2} \mathrm{O}_{5}$. Rock fragments from the Grad Member volcaniclastics tend to be enriched in almost all trace elements - Rb, Be, Sr, Ba, Ag, Zn, Th, U, Zr, Hf, Ta, W, Y, REEs, As and Sb, and depleted in $\mathrm{Cu}, \mathrm{V}, \mathrm{Ni}$ and Sc. The magma(s) producing rock fragments from the Grad Member volcaniclastics seem to be more differentiated than those from Austria. Depleted $\mathrm{CaO}$, $\mathrm{MgO}, \mathrm{TiO}_{2}, \mathrm{Cu}, \mathrm{V}, \mathrm{Ni}$ and $\mathrm{Sc}$ might be related to the removal of pyroxenes from the melt by crystal fractionation.

\section{Discussion}

The studied basaltic rock samples occupy mainly the fields of trachybasalt and basalt (Fig. 3) in the $\mathrm{Na}_{2} \mathrm{O}+\mathrm{K}_{2} \mathrm{O}$ vs. $\mathrm{SiO}_{2}$ diagram after LeBas et al. (1986). Only one sample from Klöch falls in the field of tephrite and basanite. Based on the content of alkali oxides and silica, the samples from Austria and the Grad Member volcaniclastics do not vary significantly, although the samples from the Grad Member tend to be more rich in silica at a given $\mathrm{Na}_{2} \mathrm{O}+\mathrm{K}_{2} \mathrm{O}$ content. Similar trend can be observed in the $\mathrm{Al}_{2} \mathrm{O}_{3}$ vs. $\mathrm{SiO}_{2}$ variation diagram (Fig. 4). In the diagram $\mathrm{MgO}$ vs. $\mathrm{SiO}_{2}$, the samples from Klöch, Kindsberg and Dölling are clearly separate from the others. One of the samples from Neuhaus is positioned close to the Grad Member population, while the other shows extremely low abundance of $\mathrm{MgO}$, possibly owing to alteration processes. In the diagram $\mathrm{TiO}_{2}$ vs. $\mathrm{SiO}_{2}$ the samples from Austria clearly separate from the Grad Member rock fragments. This trend is even more obvious in the diagrams of $\mathrm{SiO}_{2}$ vs. $\mathrm{Zr}$, Sc vs. $\mathrm{Zr}$ and $\mathrm{TiO}_{2}$ vs. Zr (Fig. 5); herein, a further distinction between the samples from Klöch, Kindsberg and Dölling, and Neuhaus can be seen. 


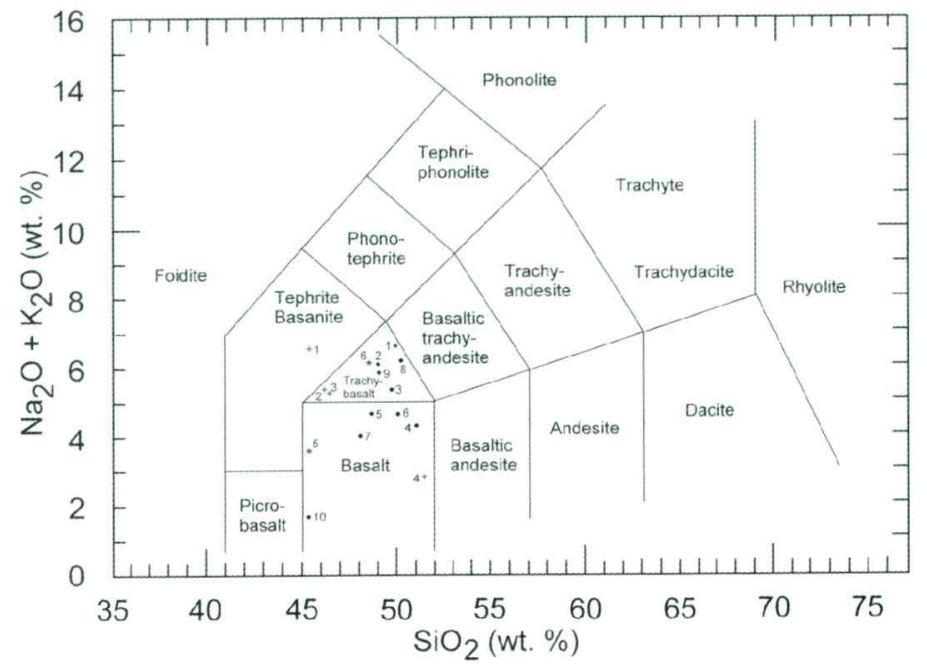

Figure 3. $\mathrm{Na}_{2} \mathrm{O}+\mathrm{K}_{2} \mathrm{O}$ vs. $\mathrm{SiO}_{2}$ (after LeBas et al., 1986) for the studied basaltic rocks. Closed circles (1-10) are for the samples from the Grad Member, crosses (1-4) for the samples from Klöch, Kindsberg and Dölling, and asterisks for the samples from Neuhaus

Slika 3. Diagram $\mathrm{Na}_{2} \mathrm{O}+\mathrm{K}_{2} \mathrm{O}$ vs. $\mathrm{SiO}_{2}$ (po LeBas-u et al., 1986) za preiskane vzorce bazaltnih kamnin. Polni krogi (1-10) predstavljajo vzorce iz Graškega člena, križi (1-4) vzorce iz Klöcha, Kindsberga in Döllinga, ter zvezdice vzorce iz Neuhausa

\section{Conclusions}

Geochemical characteristics of basaltic rocks from Klöch, Kindsberg, Dölling, and Neuhaus and basaltic rock fragments from the Grad Member volcaniclastics based on

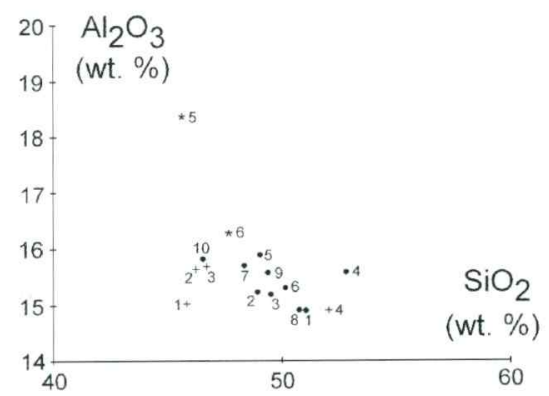
the abundance of major oxides and trace elements have shown the following:

- Chemical composition of the Grad Member rock fragments and basaltic rocks from potential source locations in Austria is different. It is not likely that the lava fragments from the Grad Member are eroded and redistributed detritus from the occurrences in Austria.

- Rock fragments from the Grad Member volcaniclastics could have two sources (volcanoes), or one, from which the magmas underwent differentiation during volcanic activity.

- Late-stage hydrovolcanic explosions produced proclastic surges, large lahars and volcanic debris flows that destroyed the former volcanic edifice(s) including lava flows and cinder cones.

In spite of numerous works (Hinterlechner-Ravnik \& Mišič, 1986; Kralj, 1995; 2000a, b; Lugović \& Kralj, 2006), the study of the Grad Member is far from completed and will continue in the future.

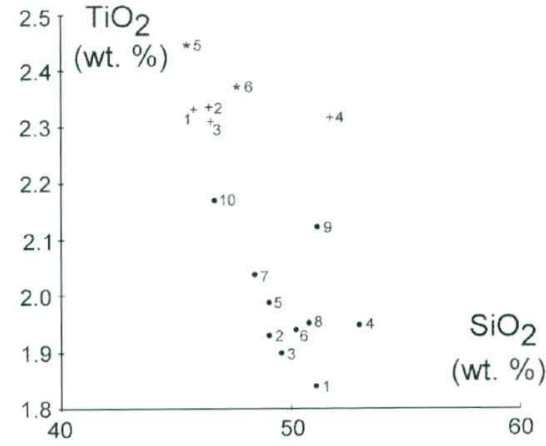

Figure 4. Variation diagrams $\mathrm{Al}_{2} \mathrm{O}_{3}$ vs. $\mathrm{SiO}_{2}, \mathrm{MgO}$ vs. $\mathrm{SiO}_{2}$, and $\mathrm{TiO}$ vs. $\mathrm{SiO}$ for the studied basaltic rock samples. Closed circles $\left(1^{2}-10\right)$ are for the samples from the Grad Member, crosses (1-4) for the samples from Klöch, Kindsberg and Dölling, and asterisks for the samples from Neuhaus

Slika 4. Variacijski diagrami $\mathrm{Al}_{2} \mathrm{O}_{3}$ napram $\mathrm{SiO}_{2}, \mathrm{MgO}$ napram $\mathrm{SiO}_{2}$ in $\mathrm{TiO}_{2}$ napram $\mathrm{SiO}_{2}$ za analizirane vzorce bazaltnih kamnin. Polni krogi (1-10) predstavljajo vzorce iz Graškega člena, križi (1-4) vzorce iz Klöcha, Kindsberga in Döllinga, ter zvezdice vzorce iz Neuhausa 

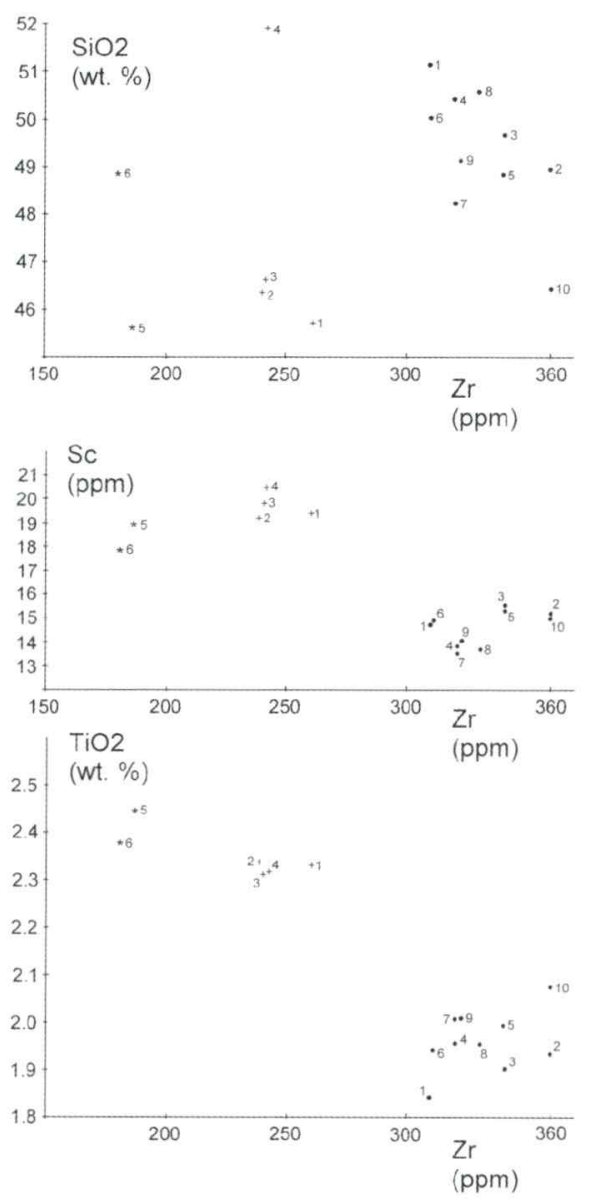

Figure 5. Variation diagrams $\mathrm{SiO}_{2}$ vs. Zr, Sc vs. $\mathrm{Zr}$, and $\mathrm{TiO}_{2}$ vs. Zr for the studied basaltic rock samples. Closed circles (1-10) are for the samples from the Grad Member, crosses (1-4) for the samples from Klöch, Kindsberg and Dölling, and asterisks for the samples from Neuhaus

Slika 5. Variacijski diagrami $\mathrm{SiO}_{2}$ napram $\mathrm{Zr}$, Sc napram $\mathrm{Zr}$ in $\mathrm{TiO}_{2}$ napram $\mathrm{Zr}$ za analizirane vzorce bazaltnih kamnin. Polni krogi (1-10) predstavljajo vzorce iz Graškega člena, križi (1-4) vzorce iz Klöcha, Kindsberga in Döllinga, ter zvezdice vzorce iz Neuhausa

\section{References}

Balogh, K., Ebner, F., Ravasz, Cs., Herrmann, P., Lobitzer, H. \& Solti, G. 1994: Alter tertiärer Vulkanite der südöstlichen Steiermark und des südlichen Burgenlands.- Jubiläumsschr. 20 Jahre Geolog. Zusammenarbeit ÖsterreichUngarn, Teil 2, 55-72, Wien.

Embey-Isztin, A. \& Kurat, G. 1996: Young alkali basalt volcanism from the Graz Basin to the Eastern Carpathians.- Advances in AustrianHungarian Joint Geological Research, 159-175, Budapest.
Hinterlechner-Ravnik, A. \& Mišič, M. 1986: Peridotitne nodule $\mathrm{v}$ bazaltnem tufu pri Gradu v Prekmurju.- Geologija 28/29, 205-218, Ljubljana.

Kisovar, M. 1979: prilog rješavanja strukturnih odnosa našeg dijela Murske depresije, ZNS, JAZU, III God. Skup. Zbor rad. Knj. I, Novi Sad, 311-322, Zagreb.

Kralj, P. 1995:Litofaciesi pliocenskog fluvialnog i vulkanoklastičnog kompleksa područja Grada u sjeveroistočnoj Sloveniji.- Ph.D. Thesis, University of Zagreb, 174 pp, Zagreb.

Kralj, P. 2000a: Accretionary lapilli in Pliocene volcaniclastics from Grad, northeastern Slovenia. - Geologija, 43/1, 67-73, Ljubljana.

Kralj, P. 2000b: Upper Pliocene alkali basalt at Grad, northeastern Slovenia. - Geologija, 43/2, 213-218, Ljubljana.

Kralj, P. 2001: Pliocene clastic sediments in Western Goričko, Northeastern Slovenia. - Geologija, 44/1, 73-79, Ljubljana.

LeBas, M. J., LeMaitre, R. W., Streckeisen, A. \& Zanettin, B. 1986: A chemical classification of volcanic rocks based on total alkali - silica diagram. - J. Petrology 27, 745-750, Oxford.

Lugović, B. \& Kralj, P. 2006: Spinel lherzolite xenoliths from Upper Pliocene potassic trachybasalts at Grad, NE Slovenia. Book of Abstracts, 2. Slovenski geološki kongres, p.64, Idrija.

Martin, U. \& Németh, K. 2004: Mio/Pliocene phreatomagmatic volcanism in the western Pannonian Basin, Hungary, U. Martin (ed.) \& K. Németh (ed.): Geologica Hungarica 26, 193 pp., Budapest.

Oberhauser, R. (ed.) 1980: Der geologische Aufbau Österreichs.- Springer, 700p., Wien.

Pleničar, M. 1968: Osnovna geološka karta SFRJ, 1:100.000, list Goričko. - Zvezni geološki zavod, Beograd.

Pleničar, M. 1970: Manuskriptna geološka karta Goričkega. - Arhiv Geološkega zavoda Slovenije, Ljubljana.

Pöschl, I. 1991: A model for the depositional evolution of the volcaniclatic successions of a Pliocene maar volcano in the Styrian basin (Austria). - Jb. Geol. B.-A. 134/4, 809-843, Wien.

Poulditis, Ch. 1981: Petrologie und geochimie basaltischer Gesteine des steirischen Vulkanbogens in der Steiermark und im Burgenland.Diss. Univ. Wien, 146 pp., Wien.

Poulditis, Ch. \& Scharbert, H. G., 1986: Bericht über geochemisch-petrologische Untersuchungen an der Transdanubischen Vulkanischen region. - Anz. Österr. Akad. Wiss., math.-naturwiss. Klasse, 123, 65-76, Wien.

Rijavec, L., Bistričić, A. \& Jenko, M. 1985: Mura Basin. - In: Steininger, F.F. (ed.), Senes, J. (ed.), Kleemann, K. (ed.) \& Rögl, F. (ed), Neogene of the Mediterranean Thethys and Paratethys $1 \& 2,73-74$. Institute of paleontology, University of Vienna, Vienna.

Śimon, J. 1966: Litostratigrafske jedinice $u$ tercijarnom kompleksu Murske potoline. - Fond struč. Dok. INA-Naftaplin, Zagreb in INA-Nafta Lendava, Zagreb.

Tollmann, A. 1986: Geologie von Österreich, Band 3.- Franz Deuticke Wien, 718p., Wien.

Winkler, A. 1927: Elauterungen zur geologischen Spezialkarte der Republik Österreich, Blatt gleichenberg. - Geologische bundesanstalt, 164 pp., Wien. 


A.
\begin{tabular}{|l|c|c|c|c|c|c|}
\hline $\begin{array}{l}\text { Sample } \\
\text { Oxide } \\
\text { (wt.\%) }\end{array}$ & $\begin{array}{c}\mathbf{1} \\
\text { Klöch 7 }\end{array}$ & $\begin{array}{c}\mathbf{2} \\
\text { Klöch 9 }\end{array}$ & $\begin{array}{c}\mathbf{3} \\
\text { Kindsberg }\end{array}$ & $\begin{array}{c}\mathbf{4} \\
\text { Dölling }\end{array}$ & $\begin{array}{c}\mathbf{5} \\
\text { Neuhaus 3 }\end{array}$ & $\begin{array}{c}\mathbf{6} \\
\text { Neuhaus 4 }\end{array}$ \\
\hline $\mathrm{SiO}_{\mathbf{2}}$ & 44,5 & 43,9 & 44,3 & 48,1 & 41,1 & 46,4 \\
\hline $\mathrm{TiO}_{2}$ & 2,27 & 2,22 & 2,19 & 2,15 & 2,21 & 2,25 \\
\hline $\mathbf{A l}_{2} \mathbf{O}_{3}$ & 14,6 & 14,8 & 14,9 & 13,8 & 16,6 & 15,9 \\
\hline $\mathbf{F e}_{\mathbf{2}} \mathbf{O}_{3}$ & 3,54 & 3,75 & 6,63 & 4,66 & 5,20 & 3,51 \\
\hline $\mathbf{F e O}$ & 5,9 & 5,3 & 2,8 & 4,0 & 3,1 & 5,2 \\
\hline $\mathbf{M n O}$ & 0,18 & 0,17 & 0,17 & 0,15 & 0,25 & 0,14 \\
\hline $\mathbf{M g O}$ & 8,98 & 8,40 & 8,58 & 7,73 & 4,61 & 6,61 \\
\hline $\mathbf{C a O}$ & 10,3 & 9,28 & 9,63 & 8,90 & 13,3 & 8,73 \\
\hline $\mathbf{N a}_{2} \mathbf{O}$ & 4,07 & 4,09 & 3,70 & 1,45 & 1,90 & 3,60 \\
\hline $\mathbf{K}_{2} \mathbf{O}$ & 2,15 & 1,47 & 1,30 & 1,11 & 1,26 & 2,22 \\
\hline $\mathbf{P}_{2} \mathbf{O}_{5}$ & 0,74 & 0,75 & 0,74 & 0,50 & 0,51 & 0,49 \\
\hline $\mathbf{H}_{2} \mathbf{O}^{+}$ & 0,9 & 2,2 & 2,5 & 4,3 & 3,2 & 3,2 \\
\hline $\mathbf{H}_{2} \mathbf{O}^{-}$ & 0,5 & 0,9 & 1,0 & 2,1 & 2,0 & 1,0 \\
\hline $\mathbf{C O}_{2}$ & 0,28 & 0,02 & 0,02 & $<0,01$ & 4,34 & 0,50 \\
\hline $\mathrm{Sum}$ & 99,48 & 98,30 & 98,75 & 99,55 & 100,2 & 100,3 \\
\hline
\end{tabular}

B.

\begin{tabular}{|l|c|c|c|c|c|c|}
\hline $\begin{array}{l}\text { Element } \\
(\mathbf{p p m})\end{array}$ & $\begin{array}{c}\mathbf{1} \\
\text { Klöch 7 }\end{array}$ & $\begin{array}{c}\mathbf{2} \\
\text { Klöch 9 }\end{array}$ & $\begin{array}{c}\mathbf{3} \\
\text { Kindsberg }\end{array}$ & $\begin{array}{c}\mathbf{4} \\
\text { Dölling }\end{array}$ & $\begin{array}{c}\mathbf{5} \\
\text { Neuhaus 3 }\end{array}$ & $\begin{array}{c}\mathbf{6} \\
\text { Neuhaus 4 }\end{array}$ \\
\hline Be & 3 & 4 & 5 & 4 & 2 & 3 \\
\hline B & 31 & 10 & 29 & 30 & $<10$ & 26 \\
\hline Sc & 19,4 & 19,2 & 19,8 & 20,5 & 18,9 & 17,9 \\
\hline V & 220 & 230 & 230 & 200 & 197 & 207 \\
\hline & & & & & & \\
\hline Cr & 140 & 120 & 110 & 120 & 137 & 178 \\
\hline Co & 46 & 43 & 45 & 48 & 43 & 56 \\
\hline Ni & 180 & 180 & 160 & 170 & 90 & 77 \\
\hline Cu & 37,4 & 40,3 & 39,4 & 37,0 & 36,8 & 41,7 \\
\hline Zn & 99,1 & 99,9 & 110,1 & 87,1 & 92,2 & 94,8 \\
\hline & & & & & & \\
\hline Rb & 71 & 59 & 31 & 51 & 32 & 67 \\
\hline Sr & 939 & 991 & 1000 & 681 & 613 & 607 \\
\hline Y & 30 & 20 & 20 & $<10$ & 37 & $<10$ \\
\hline Zr & 260 & 240 & 241 & 239 & 186 & 179 \\
\hline Nb & 101 & 111 & 131 & 99 & 57 & 59 \\
\hline Cd & 2 & 2 & $<1$ & 1 & 1 & 2 \\
\hline Sb & $<0,2$ & $<0,2$ & $<0,2$ & 0,4 & 0,2 & 0,3 \\
\hline Cs & $<1$ & 2 & 1 & 1 & 1 & 2 \\
\hline Ba & 682 & 851 & 954 & 902 & 789 & 608 \\
\hline & & & & & & \\
\hline La & 56,3 & 62,2 & 65,5 & 49,8 & 36,9 & 35,6 \\
\hline Ce & 105 & 114 & 110 & 98 & 72 & 72 \\
\hline Nd & 39 & 42 & 46 & 36 & 31 & 29 \\
\hline Sm & 6,4 & 6,8 & 7,3 & 6,7 & 5,8 & 5,5 \\
\hline Eu & 2,0 & 2,2 & 2,9 & 2,2 & 2,1 & 2,2 \\
\hline Tb & 0,6 & 0,7 & 0,8 & 0,9 & 0,7 & 0,6 \\
\hline Yb & 1,6 & 1,8 & 1,9 & 1,4 & 1,5 & 1,4 \\
\hline Lu & 0,25 & 0,25 & 0,26 & 0,20 & 0,21 & 0,19 \\
\hline & & & & & & \\
\hline Hf & 4,1 & 5,2 & 4,9 & 5,1 & 4,5 & 4,4 \\
\hline Ta & 5 & 6 & 5 & 5 & 3 & 3 \\
\hline W & 75 & 48 & 43 & 67 & 25 & 120 \\
\hline Th & 7,6 & 8,6 & 9,6 & 8,1 & 5,7 & 5,2 \\
\hline $\mathbf{U}$ & 2,6 & 3,1 & 3,2 & 1,1 & 2,4 & 1,6 \\
\hline & & & & & & \\
\hline
\end{tabular}


A.

\begin{tabular}{|c|c|c|c|c|c|c|c|c|c|c|}
\hline $\begin{array}{l}\text { Sample } \\
\text { Oxide } \\
\text { (wt. \%) }\end{array}$ & $\begin{array}{c}1 \\
\text { B } 1\end{array}$ & $\begin{array}{c}2 \\
\text { B2 }\end{array}$ & $\begin{array}{c}3 \\
\text { B } 3\end{array}$ & $\begin{array}{c}4 \\
\text { BB }\end{array}$ & $\begin{array}{c}5 \\
\text { GGo4 }\end{array}$ & $\begin{array}{c}6 \\
\mathrm{KaW}\end{array}$ & $\begin{array}{c}7 \\
\text { P } 53\end{array}$ & $\begin{array}{c}8 \\
\text { KuKlA }\end{array}$ & $\begin{array}{c}9 \\
\text { KuSc4 }\end{array}$ & $\begin{array}{c}10 \\
\text { KuSc6 }\end{array}$ \\
\hline $\mathrm{SiO}_{2}$ & 48,9 & 46,3 & 47,0 & 46,8 & 45,4 & 47,7 & 43,6 & 47,9 & 46,9 & 41,6 \\
\hline $\mathrm{TiO}_{2}$ & 1,76 & 1,83 & 1,80 & 1,81 & 1,85 & 1,85 & 1,84 & 1,85 & 1,93 & 2,43 \\
\hline $\mathrm{Al}_{2} \mathrm{O}_{3}$ & 14,3 & 14,4 & 14,4 & 14,5 & 14,8 & 14,6 & 14,2 & 14,1 & 14,9 & 14,2 \\
\hline $\mathrm{Fe}_{2} \mathrm{O}_{3}$ & 3,47 & 3,63 & 3,58 & 4,15 & 5,08 & 4,57 & 5,18 & 4,89 & 5,08 & 7,28 \\
\hline $\mathrm{FeO}$ & 5,2 & 5,3 & 5,2 & 4,7 & 4,4 & 4,6 & 4,2 & 4,3 & 4,6 & 3,7 \\
\hline $\mathrm{MnO}$ & 0,18 & 0,19 & 0,19 & 0,19 & 0,20 & 0,19 & 0,22 & 0,19 & 0,52 & 0,21 \\
\hline $\mathrm{MgO}$ & 6,34 & 6,76 & 6,66 & 6,60 & 5,93 & 6,80 & 5,93 & 5,88 & 5,55 & 6,10 \\
\hline $\mathrm{CaO}$ & 8,49 & 9,28 & 9,02 & 8,78 & 9,20 & 9,08 & 9,83 & 8,88 & 9,58 & 11,6 \\
\hline $\mathrm{Na}_{2} \mathrm{O}$ & 3,90 & 3,89 & 3,97 & 2,20 & 2,63 & 3,16 & 1,61 & 3,86 & 2,96 & 0,41 \\
\hline $\mathrm{K}_{2} \mathrm{O}$ & 2,27 & 2,11 & 2,01 & 2,20 & 2,15 & 1,79 & 1,89 & 1,99 & 2,45 & 1,15 \\
\hline $\mathrm{P}_{2} \mathrm{O}_{5}$ & 0,88 & 0,94 & 0,92 & 0,97 & 1,28 & 0,99 & 1,78 & 0,93 & 1,02 & 1,00 \\
\hline $\mathrm{H}_{2} \mathrm{O}^{+}$ & 2,0 & 2,2 & 1,9 & 3,0 & 2,9 & 3,3 & 5,6 & 2,9 & 3,4 & 5,8 \\
\hline $\mathrm{H}_{2} \mathrm{O}^{-}$ & 0,5 & 1,1 & 1,0 & 1,7 & 1,5 & 1,8 & 2,6 & 1,1 & 0,7 & 3,3 \\
\hline $\mathrm{CO}_{2}$ & 0,32 & 0,51 & 0,44 & 0,04 & 0,04 & 0,05 & 0,14 & 0,16 & 0,04 & 0,01 \\
\hline Sum & 98,87 & 99,00 & 98,51 & 99,35 & 98,96 & 100,5 & 99,37 & 99,40 & 100,3 & 100,3 \\
\hline
\end{tabular}

B.

\begin{tabular}{|c|c|c|c|c|c|c|c|c|c|c|}
\hline $\begin{array}{l}\text { Element } \\
(\mathrm{ppm})\end{array}$ & $\begin{array}{c}1 \\
\text { B } 1\end{array}$ & $\begin{array}{c}2 \\
\text { B2 }\end{array}$ & $\begin{array}{c}3 \\
\text { B } 3\end{array}$ & $\begin{array}{c}4 \\
\text { BB }\end{array}$ & $\begin{array}{c}5 \\
\text { GGo4 }\end{array}$ & $\begin{array}{c}6 \\
\mathrm{KaW}\end{array}$ & $\begin{array}{c}7 \\
\text { P } 53 \\
\end{array}$ & $\begin{array}{c}8 \\
\text { KuKlA }\end{array}$ & $\begin{array}{c}9 \\
\text { KuSc4 }\end{array}$ & $\begin{array}{c}10 \\
\text { KuSc6 }\end{array}$ \\
\hline $\mathrm{Be}$ & 6 & 4 & 3 & 6 & 5 & 4 & 5 & 4 & 5 & 4 \\
\hline B & 30 & 10 & 20 & 30 & 20 & 20 & 10 & 20 & 27 & 10 \\
\hline Sc & 14,7 & 14,2 & 14,5 & 13,8 & 14,4 & 14,8 & 14,5 & 13,6 & 14,1 & 16,1 \\
\hline $\mathrm{V}$ & 191 & 171 & 162 & 161 & 182 & 169 & 179 & 161 & 184 & 191 \\
\hline $\mathrm{Cr}$ & 120 & 130 & 120 & 110 & 130 & 120 & 92 & 100 & 140 & 180 \\
\hline Co & 25 & 37 & 43 & 39 & 51 & 25 & 28 & 52 & 42 & 38 \\
\hline $\mathrm{Ni}$ & 81 & 110 & 110 & 110 & 110 & 85 & 100 & 124 & 128 & 145 \\
\hline $\mathrm{Cu}$ & 29,4 & 36,0 & 37,2 & 36,9 & 37,5 & 29,4 & 21,9 & 34,1 & 24,7 & 29,9 \\
\hline $\mathrm{Zn}$ & 110 & 110 & 140 & 110 & 130 & 110 & 110 & 120 & 134 & 157 \\
\hline $\mathbf{R b}$ & 68 & 60 & 50 & 70 & 70 & 48 & 54 & 70 & 81 & 35 \\
\hline $\mathrm{Sr}$ & 1060 & 1160 & 1120 & 1200 & 1310 & 1150 & 1280 & 975 & 909 & 706 \\
\hline $\mathbf{Y}$ & 26 & 10 & 40 & 30 & 30 & 41 & 30 & 20 & 32 & 29 \\
\hline $\mathrm{Zr}$ & 310 & 360 & 340 & 320 & 340 & 310 & 320 & 330 & 322 & 361 \\
\hline Cd & $<0,2$ & 2 & 1 & 1 & 2 & $<0,2$ & $<0,2$ & 2 & 2 & 2 \\
\hline $\mathrm{Sb}$ & 0,7 & 0,5 & 0,6 & 0,7 & 0,7 & 0,5 & 0,6 & 0,3 & n.d. & n.d. \\
\hline Cs & 2 & 1 & 2 & 1 & 2 & 1 & 1 & 1 & 3 & 1 \\
\hline $\mathrm{Ba}$ & 920 & 900 & 920 & 1300 & 1400 & 1000 & 1100 & 970 & 1080 & 800 \\
\hline La & 73,4 & 77,8 & 74,6 & 74,5 & 80,3 & 78,3 & 90,5 & 73,8 & 81,3 & 71,8 \\
\hline $\mathrm{Ce}$ & 138 & 143 & 133 & 133 & 146 & 133 & 155 & 137 & 145 & 140 \\
\hline Nd & 57,2 & 54 & 50 & 52 & 54 & 62,1 & 63,6 & 50 & 51 & 59 \\
\hline $\mathrm{Sm}$ & 9,5 & 8,9 & 8,3 & 8,2 & 8,8 & 9,8 & 10,5 & 8,2 & 7,8 & 10,4 \\
\hline Eu & 2,8 & 2,6 & 2,6 & 2,4 & 2,7 & 3,3 & 3,2 & 2,5 & 3,7 & 3,2 \\
\hline Tb & 1,0 & 1,1 & 1,0 & 1,0 & 1,2 & 1,1 & 1,1 & 0,9 & 0,9 & 1,3 \\
\hline $\mathbf{Y b}$ & 2,3 & 2,1 & 2,3 & 2,1 & 2,6 & 2,5 & 2,8 & 2,0 & 2,2 & 2,8 \\
\hline Lu & 0,38 & 0,28 & 0,31 & 0,28 & 0,34 & 0,41 & 0,40 & 0,27 & 0,39 & 0,27 \\
\hline Hf & 8,0 & 7,1 & 7,2 & 6,1 & 7,1 & 8,4 & 7,6 & 6,2 & 6,5 & 8,4 \\
\hline Ta & 6 & 6 & 6 & 5 & 6 & 6 & 7 & 6 & 6 & 6 \\
\hline W & 150 & 110 & 120 & 130 & 160 & 110 & 97 & 370 & 170 & 14 \\
\hline Th & 12 & 11 & 11 & 11 & 11 & 11 & 12 & 11 & 11 & 13 \\
\hline $\mathbf{U}$ & 4,1 & 3,4 & 3,1 & 3,7 & 3,2 & 3,7 & 5,6 & 3,4 & 4,3 & 1,1 \\
\hline
\end{tabular}

Explanation:

n.d. - not defined 


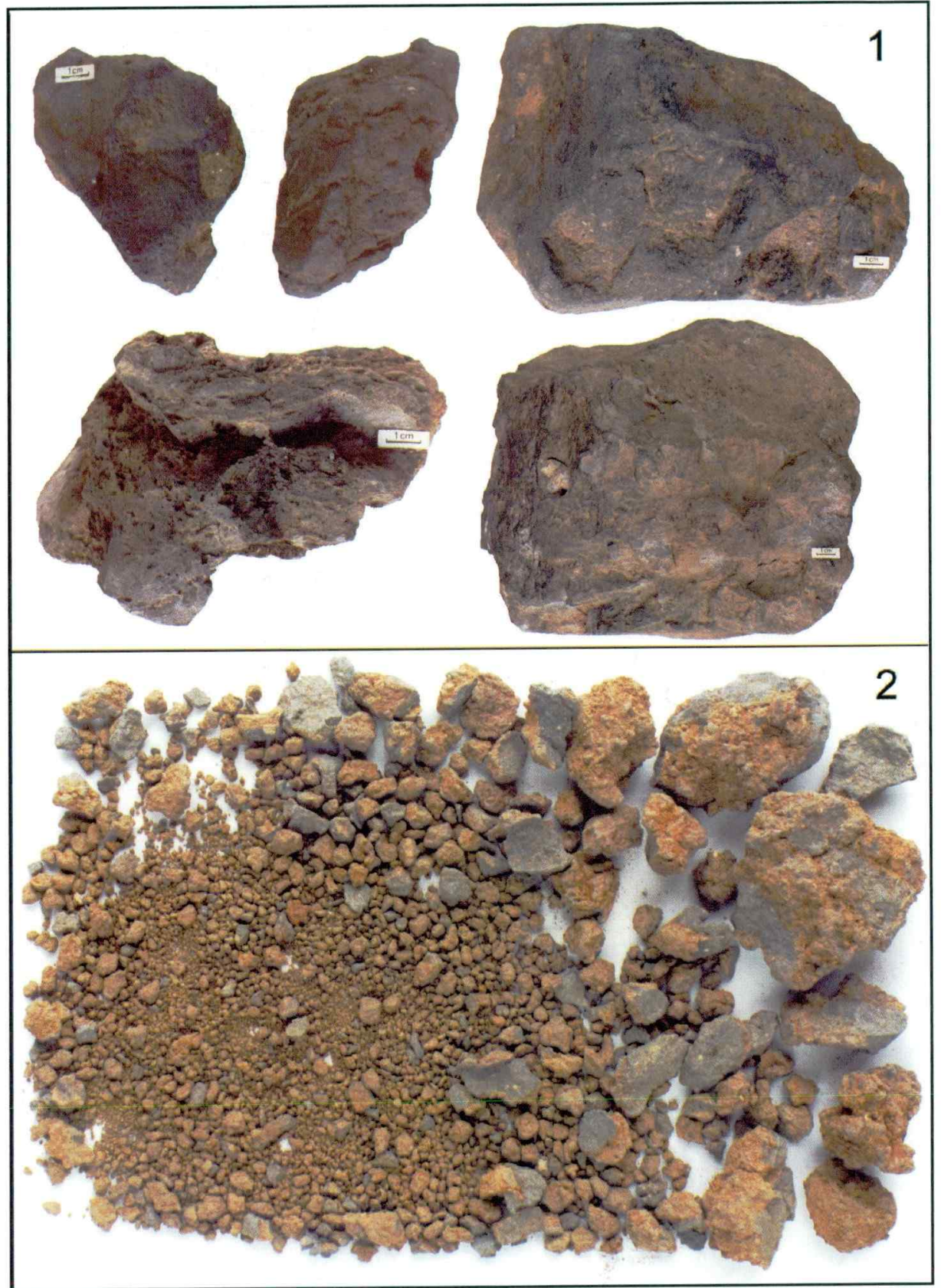

Plate 1 - Tabla 1

1 Basaltic rock fragments from the Grad Member volcaniclastics. Odlomki bazaltnih kamnin iz vulkanoklastitov Graškega člena

2 A lava sample from Neuhaus which underwent disintegration into hyaloclasts after being frozen in a solution of hydrogene peroxide. The largest clast is about $3,5 \mathrm{~cm}$ long.

Vzorec lave iz Neuhausa, ki je po zmrzovanju v raztopini vodikovega peroksida razpadel v številne hialoklaste. Največji hialoklast meri približno $3,5 \mathrm{~cm}$ v dolžino 